\title{
PHYTIC ACID (MYO-INOSITOL HEXAPHOSPHATE)- A PROMISING PHARMACEUTICAL AGENT: A REVIEW
}

\author{
RADHAKRISHNAN NARAYANASWAMY1*, NORHAIZAN MOHD ESA ${ }^{2,3}$
}

${ }^{1}$ Bio Incubator and Lab, Vel Tech Technology Incubator, Vel Tech Rangarajan Dr. Sagunthala R and D Institute of Science and Technology, 400 Feet Outer Ring Road, Avadi, Chennai, Tamil Nadu, India. ${ }^{2}$ Department of Nutrition and Dietetics, Faculty of Medicine and Health Sciences, Universiti Putra Malaysia, 43400 Serdang, Selangor, Malaysia. ${ }^{3}$ Laboratory of Molecular Biomedicine, Institute of Bioscience, Universiti Putra Malaysia, 43400 Serdang, Selangor, Malaysia. Email: nrkishnan@gmail.com

Received: 09 June 2018, Revised and Accepted: 10 July 2018

\section{ABSTRACT}

Phytic acid (myo-inositol hexaphosphate) has gained much attention among researchers for its therapeutic value. This review focuses on pharmacological activities of phytic acid, which have been demonstrated by pre-clinical studies. Anti-carcinogenic, antioxidant, antidiabetic, hypolipidemic, anti-angiogenic, and immunomodulation are the most extensively studied pharmacological activities of phytic acid. In addition to these, phytic acid and its derivatives also possess enzyme inhibitory activities against few key enzymes such as 5-alpha reductase, aldose reductase, cyclooxygenase, lipase, matrix metalloproteinase- $2 \& 9$, pepsin, polyphenol oxidase, protease, $\beta$-secretase, tyrosinase, and xanthine oxidase were emphasized. The profound pharmacological activities of phytic acid have proven to be a good therapeutic agent and could be employed in preventing as well as treating such diseases.

Keywords: Phytic acid (myo-inositol hexaphosphate), Anticarcinogenic, Hypoallergenic, 5-alpha reductase (type-2), $\beta$-Secretase (type-1).

(C) 2018 The Authors. Published by Innovare Academic Sciences Pvt Ltd. This is an open access article under the CC BY license (http://creativecommons. org/licenses/by/4. 0/) DOI: http://dx.doi.org/10.22159/ajpcr.2018.v11i11.27843

\section{INTRODUCTION}

Phytic acid is chemical known as myo-inositol hexaphosphate, which is abundant in nature and especially in plants it accounts for 1-5\% weight of edible cereals, legumes, nuts, oil seeds, and tubers [1-3]. The process of synthesizing phytic acid is metabolically expensive, which requires six adenosine triphosphate molecules for phosphorylation of each phytic acid molecule [4]. An average intake of phytate by humans on vegetarian diets is about $2000-2600 \mathrm{mg} /$ day [5]. It is readily absorbed in the gastrointestinal (GI) tract and then enters the bloodstream [6]. It is also physiologically present in the human large intestine [7].

Phytic acid is a unique negatively charged molecule in a wide $\mathrm{pH}$ range and having 12 replaceable protons in it [8]. These characteristic chemical natures allow the formation of metal complexes with polyvalent metals especially with divalent and trivalent [9]. Phytases are the only enzymes, which capable of hydrolyzing phytic acid into myo-inositol and inositol phosphates [1]. Phytic acid has been well known as anti-nutrient agent in the past. Recently, phytic acid has been extensively studied due to its numerous biological activities; therefore, it is worthwhile to review recent findings on phytic acid and its pharmacological activities. The present review, we describe the recent therapeutic potential of phytic acid as a promising pharmaceutical agent.

\section{PHARMACOLOGICAL ACTIVITIES OF PHYTIC ACID}

Few important pharmacological activities of phytic acid have been shown in Fig. 1 wherein, all these publications exemplify the numerous pharmaceutical studies and deliberately confirmed the potential therapeutic value of the phytic acid against various diseases. Furthermore, antineoplastic/anticarcinogenic activity of phytic acid has more number of studies/publications, which is followed by antioxidant activity and so on (Fig. 1).

\section{Antibacterial activity of phytic acid}

Phytic acid is the main storage form of phosphorus in many plant tissues. Recently, food-grade phosphate (including phytic acid) has gained importance among researchers, due to its usefulness as a food additive in a wide variety of meat products. A number of researchers have reported that phosphates shown to exhibit antimicrobial activities, although it has never been classified as an antimicrobial agent. Sodium phytate (sodium salt of phytic acid) has been reported to inhibit Escherichia coli growth in raw or cooked meats including beef, chicken, and pork [10]. In other study, phytic acid from rice bran has been reported to inhibit the growth of both Salmonella typhimurium and $E$. coli [11].

Antidiabetic activity of phytic acid

Yoon et al. [12] reported that phytate-enriched diets result in low blood glucose (glycemia) levels in humans. Later two reports shown that phytate regulates insulin secretion through inhibiting the serine/ threonine-specific protein phosphatase activity, which, in turn, opens intracellular calcium channels required for insulin release $[13,14]$. Kuppusamy et al. [15] reported that phytic acid has been shown to exhibit both $\alpha$-glucosidase and $\alpha$-amylase inhibition in dose-dependent manner (in vitro) and also shown to possess antidiabetic activity against streptozotocin-nicotinamide induced diabetes (type 2) in rats. In other study, phytic acid extracted from Kenyan local vegetables and grains have been shown to possess both $\alpha$-glucosidase and $\alpha$-amylase inhibition [16].

Anti-inflammatory activity of phytic acid

Recent investigations suggest that bioactive natural dietary products play a key role in the alleviation and control of inflammation-related diseases $[17,18]$. Phytic acid has been reported to exhibit antiinflammatory activity against carrageen induced paw edema in experimental rats [19].

\section{Antineoplastic/Anticarcinogenic activity of phytic acid}

Phytic acid has been shown to exhibit anticarcinogenic activity on a wide variety of tumors [20,21], which includes Barrett's adenocarcinoma [22], breast cancer [23], colon cancer [24,25], glioblastoma [26], laryngeal carcinoma [27], oral cavity squamous cell carcinoma [28], pancreatic cancer [29], prostate cancer [30], and skin cancer [31]. Key mechanism actions of phytic acid against tumors have been shown in Fig. 2. 


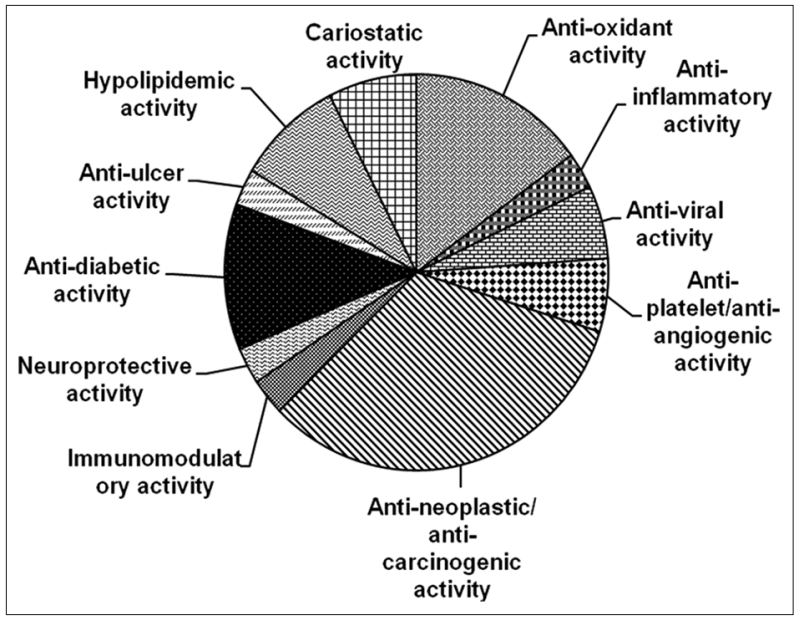

Fig. 1: Represents various pharmacological activities of phytic acid

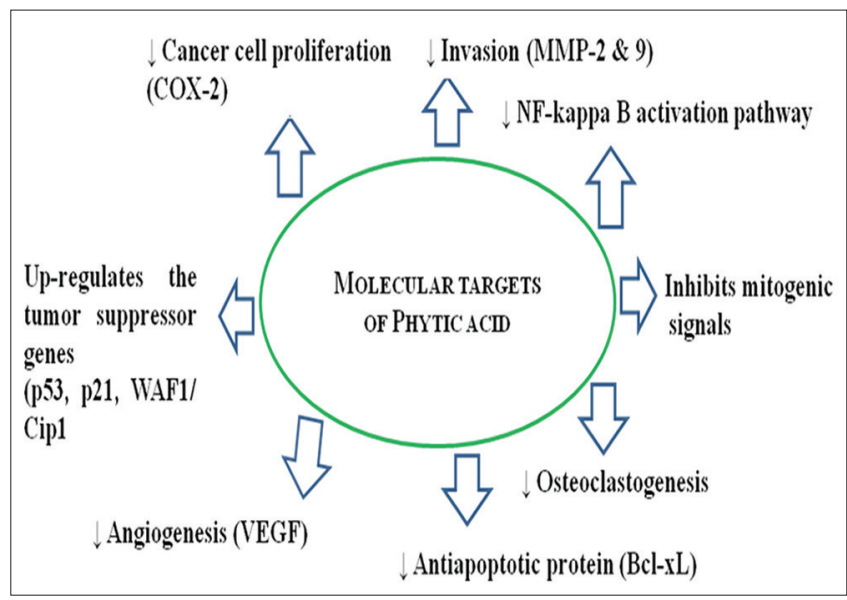

Fig. 2: Represents molecular targets of phytic acid (cyclooxygenase-2; matrix metalloproteinase; nuclear factor kappa B; B-cell lymphoma-extra large; vascular endothelial growth factor and WAF1/Cip1-wild type activating fragment 1/ cyclin-dependent kinase inhibitory protein 1)

\section{Antioxidant activity of phytic acid}

Phytic acid has been reported to inhibit the hydroxyl radical formation [32,33] and lipid peroxidation activities [1,34]. In other study, phytic acid extracted from Kenyan local vegetables and grains have been shown to possess 2,2-diphenylpicrylhydrazyl radical scavenging activity [16]. Furthermore, phytic acid has been reported to exhibit antioxidant activity [35].

\section{Antiplatelet and anti-angiogenic activity of phytic acid}

Vucenik et al. [36] reported that phytic acid inhibits human platelet aggregation in a dose-dependent manner under in vitro condition. 5 years later, phytic acid has been reported to possess anti-angiogenic activity against both in vitro and in vivo induced angiogenesis [37].

\section{Antiulcer activity of phytic acid}

Ulcer is a common GI disorder. Ulcers are lesions on the srfuace of skin or a mucous membrane clinically characterized by a superficial loss of tissue. Phytic acid has been reported to possess antiulcer activity against ibuprofen, ethanol, and cold stress-induced ulcers in experimental rats [19].

\section{Antiviral activity of phytic acid}

Phytic acid has been reported to inhibit the proliferation of human immunodeficiency virus (HIV) under in vitro condition [38]. In other study, anti-HIV1 activity of both myo-inositol hexaphosporic acid (IP6) and myo-inositol hexasulfate (IS6) has been reported in detail [39].

\section{Cariostatic activity of phytic acid}

Sodium phytate (sodium salt of phytic acid) has been shown to possess cariostatic activity using in vivo studies [40-42]. Kaufman and Kleinberg [43] reported that the cariostatic action of phytic acid and its derivatives have been attributed mainly, due to its ability to lower solubilizes of calcium, fluoride, and phosphate as they major components of tooth enamel. Phytic acid has been tested in toothpaste as a tool for preventing tooth plaque formation [44].

\section{Hemolytic activity of phytic acid}

Hemolytic activity of any substances or compounds is a measure of general cytotoxicity toward normal healthy cells. Phytic acid has not shown any hemolysis at $\geq 1 \mathrm{mM}$ concentration level, however significantly increases the percentage of annexin V-binding erythrocytes [45].

\section{Hypoallergenic activity of phytic acid}

Peanut allergy is one of the most common food allergies among the schoolchildren in United States of America (USA) and United Kingdom. Phytic acid has been shown to possess hypoallergenic activity against peanut allergens [46].

Hypolipidemic activity of phytic acid

Katayama [47] reported the hypolipidemic activity of phytic acid in rat model. Lee et al. [48] reported that dietary phytic acid reduces serum and hepatic lipid levels in aged ICR mice feed with high cholesterol diet. In other study, phytic acid has been reported to possess antihyperlipidemic activity against high fat-induced mice model [49].

\section{Immunomodulatory activity of phytic acid}

An immunomodulatory agent is a substance that may be an immunostimulator or an immunosuppressant based on its effect on the immune system. Phyticacid has been shown to possessimmunomodulatory activity against bacterial lipopolysaccharide-induced human mononuclear cells [50].

\section{Neuroprotective activity of phytic acid}

Alterations in antioxidant status in nervous tissue have been implicated in pathologies of neurodegenerative disorders such as amyotrophic lateral sclerosis, Alzheimer's disease, and Parkinson's disease. Phytic acid has been shown to possess neuroprotective activity against Parkinson's disease [51,52].

\section{Phytic acid against renal stone formation}

Renal stone disease is an ailment afflicting human beings for many centuries. A majority of renal stones are calcium stones, which account approximately $80 \%$ of all of these stones. Phytic acid has been reported to inhibit the calcium oxalate crystal formation, which, in turn, prevents renal stone formation [53,54].

\section{ENZYME INHIBITORY ACTIVITIES OF PHYTIC ACID AND ITS DERIVATIVES}

Few reported enzyme inhibitory activities of phytic acid and its derivatives have been shown in Fig. 3 and discussed below in detail. Recently, phytic acid has been reported to inhibit the enzymes such as cyclooxygenase-2 (COX-2), human neutrophil elastase, lipoxygenase, microsomal prostaglandin E synthase-2, and tyrosinase using in silico approach [55].

Phytic acid as 5-alpha-reductase inhibitor

5 -alpha-reductase is an enzyme which catalyzes conversion of testosterone to dihydrotestosterone. In men elevated enzyme activity is associated with benign prostatic hypertrophy and premature baldness. 
Phytic acid has been reported to inhibit the 5-alpha-reductase (type 2) activity using in silico study, which could prevent prostate cancer and hair fall [56].

\section{Phytic acid derivative (PP-56) as aldose reductase inhibitor}

Aldose reductase is the key regulatory enzyme in the polyol pathway, which catalyzes glucose to sorbitol. Elevated enzyme has been implicated in the development of diabetic retinopathy, leading cause of blindness. Phytic acid derivative, namely D-myo-inositol 1,2,6-trisphosphate (PP56 ) has been reported to modulate the aldose reductase activity against streptozotocin-induced diabetic rats, which could prevent diabetic cataract formation [57].

\section{Phytic acid as COX-2 inhibitor}

COX is the key regulatory enzyme which catalyzes the conversion of arachidonic acid to prostaglandins, where cyclooxygenase- 2 is mainly an inflammatory, inducible enzyme. Phytic acid has been reported to suppress the COX-2 expression in azoxymethane-induced colon cancer cells [58].

Myo-inositol phosphate ester (hydrolyzed product of phytic acid) as lipase inhibitor

Lipase is an enzyme which catalyzes the hydrolysis of fats. Elevated enzyme activity is associated with inflammatory or neoplastic disease of the pancreas. Myo-inositol phosphate ester has been reported to inhibit the lipase activity [59].

Phytic acid as matrix metalloproteinase-2 \& 9 (MMP-2 \& 9) inhibitor

MMP's are a group of zinc-dependent endopeptidase which capable of degrading extracellular matrix and are involved in remodelling and turnover of dermis [18]. Phytic acid has been reported to modulate the MMP-2 gene expression in colon cancer cells [60]. In other study, phytic acid has been reported to modulate both the MMP-2 and 9 gene expressions against phorbol-12-myristate 13-acetate stimulated colon cancer cells [61].

\section{Phytic acid as pepsin inhibitor}

Pepsin is a digestive enzyme which capable of degrading food proteins into peptides. Pepsin is one of the main causes of mucosal damage during laryngopharyngeal reflux. Phytic acid has been reported to inhibit the pepsin activity [62].

\section{Phytic acid as polyphenol oxidase (PPO) inhibitor}

PPO is copper-containing enzyme having both catecholase and cresolase activity. It plays defence role against pathogens and responsible for browning reactions. Phytic acid has been reported to inhibit the PPO activity, which could prevent browning of apple [63].

\section{Phytic acid as protease inhibitor}

Protease is a digestive enzyme, which hydrolysis protein into shorter fragments. It occurs in all organisms from prokaryotes to eukaryotes to viruses. Phytic acid has been reported to inhibit the protease activity in fish [64].

\section{Phytic acid as $\boldsymbol{\beta}$-Secretase (BACE-1) inhibitor}

BACE-1 is a rate-limiting enzyme involved in production and deposition of amyloid- $\beta$-peptide $(A \beta)$. It is now emerging as marker enzyme for the treatment of Alzheimer's disease. Phytic acid has been reported to inhibit the BACE-1 activity, which could prevent $A \beta$ accumulation [65].

\section{Phytic acid as tyrosinase inhibitor}

Tyrosinase is the main regulatory enzyme in melanogenesis process particularly in the first two steps such as (i) tyrosine hydroxylation to 3, 4-dihydroxyphenylalanine (DOPA) and (ii) the oxidation of DOPA to dopaquinone. Graf et al. [4] have reported phytic acid, as inhibitor of mushroom tyrosinase. In other study, phytic acid containing formulation (Amelan $\mathrm{M}$ ) has been shown to reduce pigmentation in melasma patients [66].

\section{Phytic acid as xanthine oxidase (XO) inhibitor}

$\mathrm{XO}$ is the key regulatory enzyme in purine metabolism. It catalyzes the oxidation of hypoxanthine to xanthine and then to uric acid. Phytic acid has been reported to inhibit the XO activity which could prevent gout [67].

\section{APPLICATIONS OF PHYTIC ACID}

Phytic acid has been reported for five major applications (Fig. 4) such as adsorption and corrosion inhibition, cosmetic, dental care, industrial, and medical applications [68].

Among these applications, food industry applications of phytic acid have been reported as predominant one, where it has been added to alcoholic beverages, bread, canned seafoods, cheese, fish meal pastes, fruits, juices, meats, miso, noodles, soy sauce, and vegetables to prevent colour and as well as to prolong shelf life of products. In 1997, Food and Drug Administration of the USA regarded sodium phytate as generally recognized as safe status for using the same as preservative in baked foodstuffs [1]. Second medical applications of phytic acid have been gaining importance among researchers, due to its potential therapeutic value $[68,69]$.

\section{CONCLUSION}

Phytic acid has shown a number of pharmacological activities such as antibacterial, antidiabetic, anti-inflammatory, anticarcinogenic, antioxidant, anti-angiogenic, antiulcer, antiviral, hypoallergenic, hypolipidemic, immunomodulation, and neuroprotection. In addition to these, phytic acid and its derivatives also posses enzyme inhibitory activities against few key enzymes such as 5 -alpha-reductase (type-2), aldose reductase, cyclooxygenase (type-2), lipase, MMP-2 and 9, pepsin, PPO, protease, BACE-1 (type-1), tyrosinase, and XO. The profound pharmacological properties have paved way for various applications

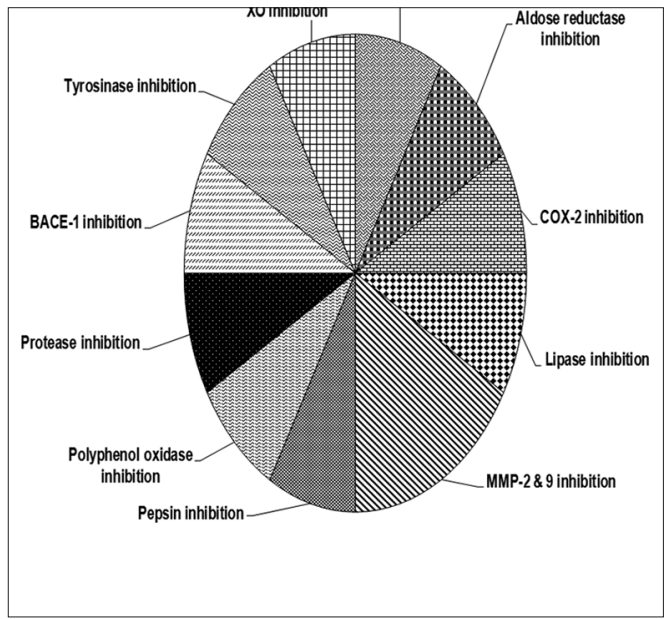

Fig. 3: Represents the enzyme inhibitory activities of phytic acid and its derivatives

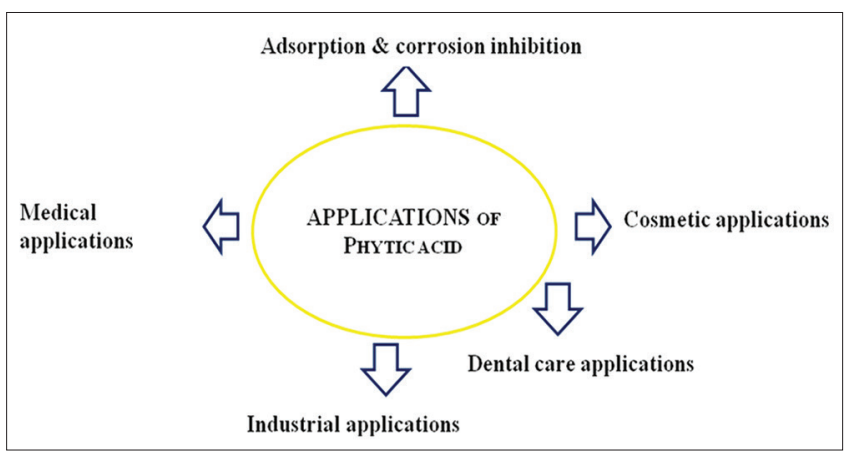

Fig. 4: Represents various applications of phytic acid 
of phytic acid. Encouraging pre-clinical studies suggest that phytic acid as a promising pharmaceutical agent for prevention and treatment of various diseases; however, more controlled clinical trials are required to demonstrate its novel therapeutic potential.

\section{AUTHORS' CONTRIBUTIONS}

RN (first author), who wrote the manuscript and submitted the same as part of PDF programme. NME (research supervisor), who had added value to it. All authors read and approved the final manuscript.

\section{CONFLICTS OF INTEREST}

The authors have declared no conflicts of interest.

\section{REFERENCES}

1. Oatway L, Vasanthan T, Helm JH. Phytic acid. Food Rev Int 2001;17:419-31.

2. Valli SA, Gowrie SU. A study on the bioactive potential of fresh and dried sprouts of Cocos nucifera L. An in vitro and in silico approach. Int J Pharm Pharm Sci 2017;9:129-42.

3. Tyagi P, Kumar Y, Gupta D, Singh H, Kumar A. Therapeutic advancements in management of iron over load-a review. Int J Pharm Pharm Sci 2015;7:35-44.

4. Graf E, Empson KL, Eaton JW. Phytic acid. A natural antioxidant. J Biol Chem 1987;262:11647-50.

5. Reddy NR. Occurrence, distribution, content, and dietary intake of phytate. In: Reddy NR, Sathe SK, editors. Food Phytates. Boca Raton: CRC; 2002. p. 25-51.

6. Shamsuddin AM. Metabolism and cellular functions of IP6: A review. Anticancer Res 1999;19:3733-6.

7. Wawszczyk J, Kapral M, Hollek A, Weglarz L. The effect of phytic acid on the expression of NF-kappaB, IL-6 and IL-8 in IL-1beta-stimulated human colonic epithelial cells. Acta Pol Pharm 2012;69:1313-9.

8. Tsao GT, Zheng Y, Lu J, Gong CS. Adsorption of heavy metal ions by immobilized phytic acid. Appl Biochem Biotechnol 1997;63-65:731-41.

9. Graf E, Eaton JW. Antioxidant functions of phytic acid. Free Radic Biol Med 1990;8:61-9.

10. Hue JJ, Li L, Lee YE, Lee KN, Nam SY, Yun YW, et al. Antibacterial activity of sodium phytate and sodium phosphates against Escherichia coli O157: H7 in meats. J Fd Hyg Saf 2007;22:37-44.

11. Han BK, Choi HJ, Park YS. Antimicrobial and antioxidative activities of phytic acid in meats. Food Eng Prog 2012;16:145-50.

12. Yoon JH, Thompson LU, Jenkins DJ. The effect of phytic acid on in vitro rate of starch digestibility and blood glucose response. Am J Clin Nutr 1983;38:835-42.

13. Larsson O, Barker CJ, Sjöholm A, Carlqvist H, Michell RH, Bertorello A, et al. Inhibition of phosphatases and increased ca2+ channel activity by inositol hexakisphosphate. Science 1997;278:471- 4 .

14. Barker CJ, Berggren PO. Inositol hexakisphosphate and beta-cell stimulus-secretion coupling. Anticancer Res 1999;19:3737-41.

15. Kuppusamy A, Muthusamy U, Thirumalaisamy SA, Varadharajan S, Ramasamy K, Ramanathan S. In vitro ( $\alpha$-glucosidase and $\alpha$-amylase inhibition) and in vivo antidiabetic property of phytic acid (IP6) in streptozotocin-nicotinamide-induced Type 2 diabetes mellitus (NIDDM) in rats. J Complement Integr Med 2011;8:1483

16. Kunyanga CN, Imungi JK, Okoth MW, Biesalski HK, Vadivel V. Antioxidant and Type 2 diabetes related functional properties of phytic acid extract from Kenyan local food ingredients: Effects of traditional processing methods. Ecol Food Nutr 2011;50:452-71.

17. Maldonado-Rojas W, Olivero-Verbel J. Potential interaction of natural dietary bioactive compounds with COX-2. J Mol Graph Model 2011;30:157-66.

18. Radhakrishnan N, Lam KW, Intan SI. In silico analysis of selected honey constituents as human neutrophil elastase (HNE) and matrix metalloproteinases (MMP 2 and 9) inhibitors. Int J Food Prop 2015;18:2155-64.

19. Sudheer Kumar M, Sridhar Reddy B, Kiran Babu S, Bhilegaonkar PM, Shirwaikar A, Unnikrishnan MK, et al. Antiinflammatory and antiulcer activities of phytic acid in rats. Indian J Exp Biol 2004;42:179-85.

20. Bozsik A, Kökény S, Olah E. Molecular mechanisms for the antitumor activity of inositol hexakisphosphate (IP6). Cancer Genomics Proteomics 2007;4:43-51.

21. Kumar V, Sinha AK, Makkar HP, Becker K. Dietary roles of phytate and phytase in human nutrition: A review. Food Chem 2010;120:945- 59.
22. McFadden DW, Riggs DR, Jackson BJ, Cunningham C. Corn-derived carbohydrate inositol hexaphosphate inhibits Barrett's adenocarcinoma growth by pro-apoptotic mechanisms. Oncol Rep 2008;19:563-6.

23. Hussein MR, Abd El-Aziz MA, Ahmad NS, Omran F, Abdulhameed M. The biochemical changes associated with phytic acid on induced breast proliferative lesions in rats: Preliminary findings. Cancer Biol Ther 2006;5:1129-33.

24. Norazalina S, Norhaizan ME, Hairuszah I, Norashareena MS. Anticarcinogenic efficacy of phytic acid extracted from rice bran on azoxymethane-induced colon carcinogenesis in rats. Exp Toxicol Pathol 2010;62:259-68.

25. Nurul-Husna S, Norhaizan ME, Hairuszah I, Abdah MA, Norazalina S, Norsharina I. Rice bran phytic acid (IP6) induces growth inhibition, cell cycle arrest and apoptosis on human colorectal adenocarcinoma cells. J Med Plants Res 2010;4:2283-9.

26. Karmakar S, Banik NL, Ray SK. Molecular mechanism of inositol hexaphosphate-mediated apoptosis in human malignant glioblastoma T98G cells. Neurochem Res 2007;32:2094-102.

27. Dorsey M, Benghuzzi H, Tucci M, Cason Z. Growth and cell viability of estradiol and IP-6 treated hep-2 laryngeal carcinoma cells. Biomed Sci Instrum 2005;41:205-10

28. Janus SC, Weurtz B, Ondrey FG. Inositol hexaphosphate and paclitaxel: Symbiotic treatment of oral cavity squamous cell carcinoma. Laryngoscope 2007;117:1381-8.

29. Somasundar P, Riggs DR, Jackson BJ, Cunningham C, Vona-Davis L, McFadden DW, et al. Inositol hexaphosphate (IP6): A novel treatment for pancreatic cancer. J Surg Res 2005;126:199-203.

30. Agarwal C, Dhanalakshmi S, Singh RP, Agarwal R. Inositol hexaphosphate inhibits constitutive activation of NF- kappa B in androgen-independent human prostate carcinoma DU145 cells. Anticancer Res 2003;23:3855-61.

31. Gupta KP, Singh J, Bharathi R. Suppression of DMBA-induced mouse skin tumor development by inositol hexaphosphate and its mode of action. Nutr Cancer 2003;46:66-72.

32. Graf E, Mahoney JR, Bryant RG, Eaton JW. Iron-catalyzed hydroxyl radical formation. Stringent requirement for free iron coordination site. J Biol Chem 1984;259:3620-4.

33. Canan C, Delaroza F, Casagrande R, Baracat MM, Shimokomaki M, Ida EI. Antioxidant capacity of phytic acid purified from rice bran. Acta Sci Technol 2012;34:457-63.

34. Zajdel A, Wilczok A, Weglarz L, Dzierżewicz Z. Phytic acid inhibits lipid peroxidation in vitro. Biomed Res Int 2013;2013:147307.

35. Norhaizan ME, Ng SK, Norashareena MS, Abdah MA. Antioxidant and cytotoxicity effect of rice bran phytic acid as an anticancer agent on ovarian, breast and liver cancer cell lines. Malays J Nutr 2011; 17:367- 75

36. Vucenik I, Podczasy JJ, Shamsuddin AM. Antiplatelet activity of inositol hexaphosphate (IP6). Anticancer Res 1999;19:3689-93.

37. Vucenik I, Passaniti A, Vitolo MI, Tantivejkul K, Eggleton P, Shamsuddin AM, et al. Anti-angiogenic activity of inositol hexaphosphate (IP6). Carcinogenesis 2004;25:2115-23

38. Otake T, Shimonaka H, Kanai M, Miyano K, Ueba N, Kunita N et al. Inhibitory effect of inositol hexasulfate and inositol hexaphosphoric acid (phytic acid) on the proliferation of the human immunodeficiency virus (HIV) in vitro. Kansenshogaku Zasshi 1989;63:676-83.

39. Otake T, Mori H, Morimoto M, Miyano K, Ueba N, Oishi I, et al. AntiHIV-1 activity of myo-inositol hexaphosphoric acid (IP6) and myoinositol hexasulfate(IS6). Anticancer Res 1999;19:3723-6.

40. Mcclure FJ. The cariostatic effect in white rats of phosphorus and calcium supplements added to the flour of bread formulas and to bread diets. J Nutr 1960;72:131-6.

41. Mcclure FJ. Cariostatic effect of phosphates. Science 1964;144:1337-8.

42. Englander HR, Keyes PH. Effect of phosphate supplements on cavitation in hamsters infected with caries-conducive streptococci. J Dent Res 1970;49:140-4

43. Kaufman HW, Kleinberg I. Effect of $\mathrm{pH}$ on calcium binding by phytic acid and its inositol phosphoric acid derivatives and on the solubility of their calcium salts. Arch Oral Biol 1971;16:445-60.

44. Vasca E, Materazzi S, Caruso T, Milano O, Fontanella C, Manfredi C, et al. Complex formation between phytic acid and divalent metal ions: A solution equilibria and solid state investigation. Anal Bioanal Chem 2002;374:173-8.

45. Eberhard M, Föller M, Lang F. Effect of phytic acid on suicidal erythrocyte death. J Agric Food Chem 2010;58:2028-33.

46. Chung SY, Champagne ET. Effects of phytic acid on peanut allergens and allergenic properties of extracts. J Agric Food Chem 2007;55:9054- 8

47. Katayama T. Hypolipidemic action of phytic acid (IP6): Prevention of 
fatty liver. Anticancer Res 1999;19:3695-8.

48. Lee SH, Park HJ, Chun HK, Cho SY, Jung HJ, Cho SM, et al. Dietary phytic acid improves serum and hepatic lipid levels in aged ICR mice fed a high-cholesterol diet. Nutr Res 2007;27:505-10.

49. Kang MY, Kim SM, Rico CW, Lee SC. Hypolipidemic and antioxidative effects of rice bran and phytic acid in high fat-fed mice. Food Sci Biotechnol 2012;21:123-8.

50. Weglarz L, Parfiniewicz B, Mertas A, Kondera-Anasz Z, JaworskaKik M, Dzierzewicz Z. Effect of inositol hexaphosphate on lipopolysaccharide-stimulated release of TNF-alpha from human mononuclear cells. Pol J Environ Stud 2008;17:283-90.

51. Xu Q, Kanthasamy AG, Reddy MB. Neuroprotective effect of the natural iron chelator, phytic acid in a cell culture model of Parkinson's disease. Toxicology 2008;245:101-8.

52. Lv Y, Zhang Z, Hou L, Zhang L, Zhang J, Wang Y, et al. Phytic acid attenuates inflammatory responses and the levels of NF- $\kappa B$ and p-ERK in MPTP-induced Parkinson's disease model of mice. Neurosci Lett 2015;597:132-6.

53. Grases F, Garcia-Gonzalez R, Torres JJ, Llobera A. Effects of phytic acid on renal stone formation in rats. Scand J Urol Nephrol 1998;32:261-5.

54. Selvam R. Calcium oxalate stone disease: Role of lipid peroxidation and antioxidants. Urol Res 2002;30:35-47.

55. Narayanaswamy R, Wai LK, Esa NM. Molecular docking analysis of phytic acid and 4-hydroxyisoleucine as cyclooxygenase-2, microsomal prostaglandin E synthase-2, tyrosinase, human neutrophil elastase, matrix metalloproteinase- 2 and -9 , xanthine oxidase, squalene synthase, nitric oxide synthase, human aldose reductase, and lipoxygenase inhibitors. Pharmacogn Mag 2017;13:S512-S518.

56. Sharma S. Screening of Natural Inhibition of 5-Alpha Reductase Type 2 for Treatment of Prostate Cancer - An in Silico Approach. Master Thesis 2010 Submitted to Mehsana Urban Institute of Sciences, Ganpat University, Gujrat, India.

57. Ruf JC, Ciavatti M, Gustafsson T, Renaud S. Effect of D-myo-inositol on platelet function and composition and on cataract development in streptozotocin-induced diabetic rats. Biochem Med Metab Biol 1992;48:46-55.

58. Saad N, Esa NM, Ithnin H. Suppression of $\beta$-catenin and cyclooxygenase- 2 expression and cell proliferation in azoxymethaneinduced colonic cancer in rats by rice bran phytic acid (PA). Asian Pac J Cancer Prev 2013;14:3093-9.

59. Knuckles BE. Effect of phytate and other myo-inositol phosphate esters on lipase activity. J Food Sci 1988;53:250-2.

60. Kapral M, Wawszczyk J, Jurzak M, Dymitruk D, Weglarz L. Evaluation of the expression of metalloproteinases 2 and 9 and their tissue inhibitors in colon cancer cells treated with phytic acid. Acta Pol Pharm 2010;67:625-9.

61. Kapral M, Wawszczyk J, Hollek A, Dymitruk D, Weglarz L. Inhibitory effect of inositol hexaphosphate on metalloproteinases transcription in colon cancer cells stimulated with phorbol-12-myristate 13-acetate. Acta Pol Pharm 2012;69:1307-12.

62. Yu S, Cowieson A, Gilbert C, Plumstead P, Dalsgaard S. Interactions of phytate and myo-inositol phosphate esters (IP1-5) including IP5 isomers with dietary protein and iron and inhibition of pepsin. J Anim Sci 2012;90:1824-32.

63. Du Y, Dou S, Wu S. Efficacy of phytic acid as an inhibitor of enzymatic and non-enzymatic browning in apple juice. Food Chem 2012;135:580- 2 .

64. Khan A, Ghosh K. Evaluation of phytase production by fish gut bacterium, Bacillus subtilis, for processing of Ipomea aquatica leaves as probable aquafeed ingredient. J Aquat Food Prod Technol 2013;22:508-19.

65. Abe TK, Taniguchi M. Identification of myo-inositol hexakisphosphate (IP6) as a $\beta$-secretase 1 (BACE1) inhibitory molecule in rice grain extract and digest. FEBS Open Bio 2014;4:162-7.

66. Levy JL, Pons F, Agopian L, Besson R. A double-blind controlled study of a nonhydroquinone bleaching cream in the treatment of melasma. J Cosmet Dermatol 2005;4:272-6.

67. Muraoka S, Miura T. Inhibition of xanthine oxidase by phytic acid and its antioxidative action. Life Sci 2004;74:1691-700.

68. GrafE. Applications of phytic acid. JAm Oil Chem Soc 1983;60:1861- 7 .

69. Ravichandran R, Seitz V, Venugopal JR, Sridhar R, Sundarrajan S, Mukherjee S, et al. Mimicking native extracellular matrix with phytic acid-crosslinked protein nanofibers for cardiac tissue engineering. Macromol Biosci 2013;13:366-75. 